\title{
Biosistem Pertanian Apel Lokal Malang
}

\author{
Dian Siswanto, Irfan Mustafa, Gustini Ekowati, Muhamad Imam, Endri Purnomo
}

Jurusan Biologi, Fakultas MIPA, Universitas Brawijaya, Malang, Indonesia

\begin{abstract}
Abstrak
Biosistem yang digambarkan pada hasil observasi di sini adalah suatu keadaan faktor biotik dan abiotik pada pertanian apel yang tidak terbatas pada suatu nilai yang tetap. Data yang diperoleh dari tiga tahapan penelitian ini diharapkan dapat dipergunakan sebagai informasi yang mendukung upaya konsevasi pertanian apel. Tahapan penelitian tersebut meliputi evaluasi nutrisi makro tanah dan tanaman, formulasi pengomposan kotoran sapi diperkaya (menggunakan bakteri indigenus) dan eksplorasi tanaman penutup tanah pertanian apel. Kandungan beberapa nutrisi makro untuk tanah pertanian apel Bumiaji menunjukkan nilai rata-rata yang berada pada kisaran sedang dan tinggi. Hasil analisis makro nutrisi daun apel yang kemudian dibandingkan dengan standar menurut Utah Fertilizer Guide menunjukkan bahwa makro nutrisi $\mathrm{N}, \mathrm{P}, \mathrm{Ca}$ berada pada status normal, $\mathrm{K}$ berada pada status kurang dan Mg berlebih. Ketersediaan nutrisi di tanah dapat dipelihara dengan penambahan kompos. Kotoran sapi yang diperkaya dengan bakteri indigen mampu mendekomposisi kotoran sapi dalam waktu 2-3 minggu. Proses dekomposisi kotoran sapi berlangsung lebih cepat pada pemberian bakteri indigenus yang mempunyai kemampuan selulolitik dan sekaligus proteolitik serta amilolitik apabila dibandingkan kontrol yang tanpa pemberian inokulum bakteri. Pada pertanian apel di Poncokusumo, kondisi lahan dengan sistem penyiangan cs (cukup sering) dan sj (sangat jarang) tampak lebih stabil daripada ss (sering sekali) berdasarkan nilai ID (indek diversitas), DR (dominansi relatif) dan INP (indek nilai penting). Hal ini diperjelas oleh nilai biomassa tanaman. Biomassa yang lebih tinggi menyebabkan suhu tanah yang lebih rendah karena jumlah TPT yang banyak mempunyai konsekuensi mengandung banyak air pada jaringannya.
\end{abstract}

Kata kunci: Apel, nutrisi makro, kompos diperkaya, tanaman penutup tanah

\section{PENDAHULUAN}

Apel (Malus sylvestris Mill) merupakan produk buah-buahan unggulan di Malang Raya dan telah menjadi ikon pariwisata daerah. Namun, produk unggulan lokal tersebut mulai menghadapi tantangan serius terutama sejak masuknya produk impor. Ukuran buah apel lokal yang relatif kecil, permukaan buah yang terkadang kusut, rasa dan aroma buah yang terkadang juga masam, serta warna buah yang kurang menarik menjadi kendala utama untuk bersaing dengan produk impor. Meningkatnya volume buah apel impor ke pasar semakin menurunkan harga jual apel lokal. Sudah hampir delapan tahun para petani selalu merugi akibat harga apel yang terus merosot. Harga apel yang melemah membuat banyak petani apel yang telah mencabut pohon apelnya dan mengganti lahannya dengan tanaman sayur [1]. Hal ini

\footnotetext{
* Alamat korespondensi penulis:

Dian Siswanto

E-mail : diansiswanto@brawijaya.ac.id

Alamat : Jurusan Biologi, Fakultas Matematika dan Ilmu Pengetahuan Alam, Universitas Brawijaya, Jl. Veteran, Malang, 65145
}

berpotensi menghilangkan ikon pariwisata daerah. Oleh karena itu diperlukan suatu upaya konservasi tanaman apel supaya tanaman tersebut tidak menjadi langka.

Para petani mengembangkan sistem pertanian apel berdasarkan pengetahuan yang mereka miliki secara turun temurun. Seiring dengan perkembangan teknologi pemupukan, sistem pertanian apel lokal malang menggabungkan kearifan tradisional dengan sistem pertanian intensif. Bagaimanapun, sistem pertanian apel lokal yang telah berjalan ini perlu dievaluasi kelebihan dan kekurangannya sehingga dapat dilakukan perbaikan sistem yang melibatkan partisipasi masyarakat petani secara aktif sebagai suatu upaya mengkonservasi pertanian apel.

Selama ini, petani selalu memberikan pemupukan NPK secara rutin tanpa mengetahui kandungan mineral tersebut di tanah, meskipun pupuk kandang juga masih digunakan. Pengetahuan tentang kandungan mineral tanah sangat penting diketahui sebelum adanya pemupukan karena tanaman membutuhkan nutrisi dalam konsentrasi tertentu untuk 
mendapatkan pertumbuhan yang optimum. Kekurangan atau kelebihan nutrisi di tanah justru akan mengganggu pertumbuhan tanaman sehingga kualitas buah juga akan terpengaruh. Adapun perbaikan kualitas tanah dapat dilakukan dengan penambahan kompos yang dapat dibuat sendiri oleh petani dari bahan baku kotoran sapi. Umumnya, para petani apel di Malang Raya terutama di Kecamatan Poncokusumo juga beternak sapi selain berkebun. Kotoran sapi yang dihasilkan bisa dimanfaatkan sebagai bahan baku organik untuk pembuatan kompos. Sebagian petani apel di Kecamatan Poncokusumo telah melakukan pengomposan kotoran sapi. Namun proses pengomposan berlangsung hingga berbulan-bulan sehingga kotoran sapi yang sedang mengalami pengomposan nampak menumpuk. Proses pengomposan yang berlangsung lama tersebut bisa dipersingkat dengan pengayaan bakteri pada kotoran sapi.

Selain sistem pemupukan, sistem pengaturan tanaman penutup tanah pada tanaman apel juga sangat menarik. Pertanian apel lokal banyak dijumpai menggunakan tiga sistem penyiangan yang berbeda, yaitu dengan frekuensi sangat sering (ss) karena pertanian apel dikombinasikan dengan tanaman palawija (diantaranya adalah kacang tanah), cukup sering (cs) untuk pengkombinasian tanaman apel dengan tanaman jagung dan pohon sengon serta sangat jarang (sj) yang menyebabkan lahan apel banyak ditumbuhi rerumputan. Perbedaan sistem ini menyebabkan perbedaan komposisi tanaman penutup tanah (TPT) yang sangat menarik untuk dikaji nilai relatif dari kerapatan, frekuensi dan dominansinya sehingga didapatkan Indeks Nilai Penting (INP) yang dapat digunakan dalam pendugaan sifat habitat dari lingkungan yang diduduki vegetasi tersebut serta memperkirakan kondisi lingkungan yang bersangkutan.

\section{METODE PENELITIAN}

Data yang dituliskan dalam studi kasus biosistem pertanian apel lokal Malang ini didapatkan dari tiga tahapan penelitian. Tahapan penelitian tersebut meliputi: evaluasi nutrisi makro tanah dan tanaman, formulasi pengomposan kotoran sapi diperkaya (menggunakan bakteri indigenus) serta eksplorasi tanaman penutup tanah pertanian apel.

Penelitian evaluasi nutrisi makro tanah dan tanaman dilakukan di Laboratorium Tanah Jurusan Pertanian, Laboratorium Biokimia Jurusan Kimia, Universitas Brawijaya serta lahan pertanian apel di Kecamatan Bumiaji, Batu.
Pengambilan contoh tanah dan daun apel dilakukan sebanyak tiga kali, dua kali pada bulan Mei dan satu kali pada bulan September 2007. Pengambilan contoh dilakukan secara komposit dengan tiga kali ulangan. Contoh tanah diambil berdasarkan Utah Fertilizer Guide untuk lahan pertanian yang seragam dengan kedalaman 0-12 inci (Sampling Uniform Field) sedangkan contoh daun diwakili oleh daun keempat termuda dari sebuah cabang [11]. Masing-masing contoh tanah dan daun dianalisis kandungan $\mathrm{N}, \mathrm{P}, \mathrm{K}, \mathrm{Ca}$ dan $\mathrm{Mg}$. Kandungan $\mathrm{N}$ diukur menggunakan metode Kjeldahl, P menggunakan metode Olsen, metode $\mathrm{HCl} 25 \%$ untuk $\mathrm{K}, \mathrm{Ca}$ dan $\mathrm{Mg}$ dianalisis menggunakan metode kapasitas tukar kation.

Penelitian formulasi pengomposan kotoran sapi menggunakan bakteri indigenus berlangsung mulai bulan Agustus sampai dengan bulan Desember 2009 dan dilaksanakan di lahan pertanian apel Pandansari, Kecamatan Poncokusumo. Bakteri selulolitik, amilolitik, dan proteolitik diisolasi dari kotoran sapi menggunakan media CMC broth, media starch broth, dan media skim broth. Masing-masing suspensi tersebut diaerasi dengan menggunakan shaker dengan kecepatan $120 \mathrm{rpm}$ pada suhu ruang selama 48 jam kecuali untuk selulolitik masa inkubasinya diperlama hingga 7 hari. Setelah inkubasi selesai, dilakukan pencawanan (metode pour plate) dengan menginokulasikan 1 $\mathrm{ml}$ suspensi dari masing-masing media. Pengujian potensi selulolitik, amilolitik, dan proteolitik dilakukan secara kualitatif dengan metode totol, yaitu mengukur indeks zona bening di sekitar koloni yang tumbuh pada media selektif. Visualisasi indeks zona bening dilakukan dengan menggunakan pewarna Congo red (1 $\left.\mathrm{mgml}^{-1}\right)$ untuk selulolitik dan reagen lodium untuk amilolitik. Isolat yang memiliki indeks zona bening terbesar dipilih sebagai inokulum untuk proses dekomposisi. Stok inokulum dibuat dengan menginokulasikan 1 oose isolat yang sudah diremajakan ke media $2 \%$ molase broth dan diaerasi dengan menggunakan shaker berkecepatan 120 rpm selama 48 jam. Kemudian, semua stok inokulum diinokulasikan menjadi satu ke dalam media produksi inokulum 3\% molase broth dan diinkubasi pada suhu ruang selama 72 jam. Volume stok yang diinokulasikan sebanyak $10 \%$ dari media produksi inokulum. Selanjutnya kultur dalam media produksi inokulum tersebut digunakan sebagai starter untuk proses pengomposan (dekomposisi) kotoran sapi dan serasah tanaman. Densitas starter yang digunakan adalah sebesar $10^{8} \mathrm{cfuml}^{-1}$. Inokulum 
sebanyak $10 \%$ dari bahan baku kompos dicampur merata dengan bahan baku kompos. Bahan baku kompos yang digunakan adalah $95 \mathrm{~kg}$ kotoran sapi dan 5 kg serasah. Sebagai kontrol dilakukan pengomposan tanpa pemberian inokulum. Masing-masing perlakuan tersebut dilakukan perulangan sebanyak 3 kali. Selama proses pengomposan berlangsung dijaga kadar airnya supaya berada di kisaran $40 \%$ dengan penambahan air. Suhu, $\mathrm{pH}, \mathrm{CN}$ rasio, dan kandungan organiknya diamati sampai proses pengomposan selesai. Setiap empat hari kompos dibalik untuk mencegah terbentuknya kondisi anaerob. Kompos yang sudah jadi kemudian diujicobakab terhadap bibit apel.

Eksplorasi tanaman penutup tanah pertanian apel dilakukan pada bulan Mei 2010 di lahan apel yang sudah ditentukan sebelumnya, meliputi lahan tanaman apel dengan sistem penyiangan ss, cs dan sj. Setiap lahan ditentukan 3 lokasi sampling secara acak. Metode analisis vegetasi yang dilakukan menggunakan metode Garis Menyinggung sepanjang $2 \mathrm{~m}$ diambil secara acak. Keragaman dan kepadatan setiap TPT pada setiap lokasi sampling ditentukan dengan cara menghitung semua jenis dan jumlah tanaman yang dilalui oleh garis yang sudah dipasang dan dicatat datanya. Contoh setiap tanaman yang ditemukan diberi label, dan disimpan kemudian dilakukan determinasi menggunakan nama lokal yang sering digunakan oleh petani apel di Poncokusumo. Suhu tanah setiap lokasi diukur menggunakan termometer digital. Dibuat plot kecil dengan ukuran $25 \mathrm{~cm} \times 25 \mathrm{~cm}$ untuk pengambilan sampel semua tanaman yang ada di dalam plot tersebut kemudian dianalisis biomassanya.

\section{HASIL DAN PEMBAHASAN}

Ketersediaan nutrisi di dalam tanah akan mempengaruhi keberadaan nutrisi tersebut di dalam jaringan tanaman. Hubungan antar ketersediaan nutrisi ditanah dengan di tanaman dapat disimpulkan apabila pengukuran sifat kimia tanah telah dilakukan secara temporal dan berkesinambungan sebelum dilakukan pengukuran kandungan nutrisi tersebut di jaringan tanaman. Kandungan beberapa nutrisi makro untuk tanah pertanian apel Bumiaji menunjukkan nilai rata-rata yang berada pada kisaran sedang dan tinggi. Hal ini berbeda dengan data sifat tanah Poncokusumo yang digunakan sebagai pembanding. Pada lahan Poncokusumo, semua parameter cenderung rendah, kecuali $\mathrm{N}$ dan K (tabel 1).
Tabel 1. Sifat Kimia Tanah Pertanian Apel Lokal Malang

\begin{tabular}{|c|c|c|c|}
\hline \multirow[b]{2}{*}{ Parameter } & \multicolumn{2}{|c|}{ Lahan Bumiaji, Batu } & \multirow{2}{*}{$\begin{array}{c}\text { Lahan } \\
\text { Poncokusumo } \\
\text { Malang *) }\end{array}$} \\
\hline & $\begin{array}{l}\text { Mei } \\
2007\end{array}$ & $\begin{array}{c}\text { September } \\
2007\end{array}$ & \\
\hline $\mathrm{N}(\%)$ & $\begin{array}{c}0.26 \\
136.24\end{array}$ & $\begin{array}{c}0.26 \\
306.6\end{array}$ & 0.203 \\
\hline$P(p p m)$ & (P Bray1) & (P. Bray1) & 11.635 \\
\hline $\mathrm{K}$ (me/100g) & 2.36 & 18.3 & 1.5 \\
\hline $\mathrm{Ca}(\mathrm{me} / 100 \mathrm{~g})$ & 7.84 & 9.93 & 1.76 \\
\hline $\mathrm{Mg}(\mathrm{me} / 100 \mathrm{~g})$ & 5.28 & 1.85 & 3.22 \\
\hline
\end{tabular}

Keterangan: ${ }^{*}$ ) analisis tahun 2004 [12]

Intrepretasi ketersediaan nutrisi pada tanaman dapat dilakukan berdasarkan jumlah nutrisi yang ada pada daun (data lengkap tidak ditampilkan). Hasil analisis makro nutrisi daun yang kemudian dibandingkan dengan standar menurut Utah Fertilizer Guide menunjukkan bahwa makro nutrisi N, P, Ca berada pada status normal, $\mathrm{K}$ berada pada status kurang dan $\mathrm{Mg}$ berlebih [11]. Gejala kekurangan makronutrisi kalium tidak dapat terdeteksi dengan cepat. Gejala awal yang mungkin terjadi adalah pengurangan kecepatan pertumbuhan kemudian klorosis dan nekrosis akan muncul sesudahnya, adapun pengaruh yang muncul pada buah adalah berkurangnya tingkat keasaman apel. Kekurangan kalium juga menyebabkan berkurangnya ketahanan tanaman terhadap kekeringan dan memudahkan tanaman terserang berbagai fungi patogen [13]. Berbeda dengan status makro nutrisi kalium yang kurang, magnesium berada pada status lebih. Pada tumbuhan, magnesium merupakan makro nutrisi yang berfungsi sebagai aktivator reaksi enzimatik dan juga merupakan komponen utama dari molekul klorofil [14]. Tidak ada gejala-gejala khusus yang disebabkan langsung oleh kelebihan magnesium. Magnesium yang berlebih di dalam jaringan tanaman dapat menghambat penyerapan kalsium, kalium dan kadangkala menghambat penyerapan besi [15].

Ketersediaan nutrisi di tanah dapat dipelihara dengan penambahan kompos. Petani seringkali menambahkan kotoran sapi yang sudah kering pada tanaman apelnya. Pengomposan kotoran sapi akan menyediakan bentuk anorganik yang lebih mudah diserap oleh tanaman. Kotoran sapi yang diperkaya dengan bakteri indigen mampu mendekomposisi kotoran sapi dalam waktu 2-3 minggu. Proses dekomposisi kotoran sapi berlangsung lebih cepat pada pemberian bakteri indigenus dibandingkan kontrol yang tanpa pemberian inokulum bakteri. 
Isolasi bakteri dari kotoran sapi dengan menggunakan tiga jenis media mendapatkan empat koloni berbeda pada media Skim agar, empat koloni berbeda pada media Starch agar, dan delapan koloni berbeda pada media CMC agar. Masing-masing koloni yang terdeteksi tersebut dipisahkan dari koloni lainnya ke medianya masing-masing di cawan petri. Kemudian dilakukan seleksi dengan mengamati keberadaan zona bening yang merupakan aktivitas enzimatis ekstraselular. Seleksi tersebut menunjukkan bahwa dari empat koloni berbeda yang terisolasi sebelumnya pada media Skim agar, hanya dua koloni yang menunjukkan adanya zona bening. Sedangkan dua koloni berbeda pada Starch agar, keduanya menunjukkan adanya zona bening. Delapan koloni berbeda yang terisolasi pada media CMC agar, hanya lima koloni yang menunjukkan adanya zona bening.

Tabel 1. Uji silang untuk mendeteksi kemampuan dekomposisi berbagai senyawa.

\begin{tabular}{lccc}
\hline \multicolumn{1}{c}{ Isolat bakteri } & $\begin{array}{c}\text { Media } \\
\text { CMC }\end{array}$ & $\begin{array}{c}\text { Media } \\
\text { starch }\end{array}$ & $\begin{array}{c}\text { Media } \\
\text { skim }\end{array}$ \\
\hline Proteolitik 1 & - & - & + \\
Proteolitik 2 & - & - & + \\
Amilolitik 1 & - & + & - \\
Amilolitik 2 & - & + & + \\
Selulolitik 1 (S1) & + & + & + \\
Selulolitik 2 (S2) & + & + & + \\
Selulolitik 3 (S3) & + & + & + \\
Selulolitik 4 (S4) & + & + & + \\
Selulolitik 5 (S5) & + & + & + \\
\hline
\end{tabular}

Keterangan:

(-) : tidak menunjukkan adanya zona

(+) : menunjukkan adanya zona bening

Semua isolat bakteri yang menunjukkan adanya zona bening dipilih untuk menjadi subjek dalam uji silang. Jadi bakteri proteolitik yang tumbuh di media Skim agar juga dikulturkan di media Starch agar dan CMC agar untuk mengetahui potensinya dalam mendegradasi Starch dan CMC (selulosa). Begitu juga untuk bakteri amilolitik (yang terisolasi dari Starch agar) dan bakteri selulolitik (yang terisolasi dari CMC agar) dikulturkan di media berbeda dari media isolasinya. Adapun hasil yang diperoleh ditampilkan pada Tabel 1. Berdasarkan hasil uji silang tersebut, diputuskan bahwa bakteri yang digunakan sebagai inokulum untuk proses pengomposan adalah kelima bakteri selulolitik tersebut. Hal ini disebabkan karena hanya kelima bakteri selulolitik tersebut yang memiliki kemampuan untuk mendegradasi protein, amilum, dan selulosa sekaligus.

Uji kualitatif aktivitas selulolitik dilakukan terhadap kelima isolat terpilih. Isolat ditumbuhkan pada media CMC agar kemudian diukur selisih luas keseluruhan zona bening dengan luas koloninya. Hasil pengukuran selisih luas tersebut menunjukkan bahwa kelima isolat memiliki kemampuan berbeda dalam menghasilkan enzim selulolitik (Tabel 2).

Tabel 2. Hasil pengukuran uji kualitatif aktivitas selulolitik dari kelima isolat

\begin{tabular}{cc}
\hline Isolat & Selisih luas zona bening $\left(\mathbf{m m}^{2}\right)$ \\
\hline S1 & 283 \\
S2 & 153 \\
S3 & 207 \\
S4 & 59 \\
S5 & 302 \\
\hline
\end{tabular}

Pada saat awal penambahan inokulum bakteri dengan bahan baku kompos yang lain, suhu yang teramati adalah $24{ }^{\circ} \mathrm{C}$. Selanjutnya, terjadi peningkatan suhu secara signifikan pada hari pertama yaitu mencapai $42{ }^{\circ} \mathrm{C}$ yang merupakan suhu tertinggi pada perlakuan. Sedangkan, pada kontrol juga mengalami hal yang sama namun panas yang dihasilkan hanya mencapai $40{ }^{\circ} \mathrm{C}$. Hal ini menunjukkan adanya aktivitas mikroba dalam mendegradasi bahan baku kompos baik pada perlakuan maupun pada kontrol. Aktivitas tersebut dilakukan oleh mikroba indigen yang berasal dari bahan baku kompos dan pada perlakuan dibantu oleh bakteri yang ditambahkan sebagai inokulum. Pada minggu kedua terjadi penurunan suhu secara bertahap dan suhu mulai stabil di titik rendah pada akhir minggu ketiga yang menunjukkan bahwa proses pengomposan telah berakhir. Selama berlangsungnya pengomposan, $\mathrm{pH}$ kompos cenderung statis di kisaran 7,9-8,0 baik pada perlakuan maupun pada kontrol. Sedangkan parameter lain seperti suhu, $\mathrm{CN}$ rasio dan kandungan organik mengalami perubahan yang berarti.

$\mathrm{CN}$ rasio dan kandungan organik pada perlakuan maupun pada kontrol nampak terjadi penurunan. Secara berturut-turut penurunan $\mathrm{CN}$ rasio dan kandungan organik pada perlakuan adalah sebesar 24,1\% dan 27,7\% (Gambar 1). Sedangkan pada kontrol, penurunan $\mathrm{CN}$ rasio dan kandungan organik berturut-turut adalah sebesar $11,3 \%$ dan $13,6 \%$. Data tersebut menunjukkan bahwa penurunan $\mathrm{CN}$ rasio dan kandungan organik pada perlakuan lebih besar daripada 
kontrol. Secara statistik persentase penurunan $\mathrm{CN}$ rasio antara perlakuan dengan kontrol adalah berbeda nyata sedangkan persentase penurunan kandungan organik tidak berbeda nyata.

Penurunan $\mathrm{CN}$ rasio dan kandungan organik yang lebih besar tersebut menunjukkan proses dekomposisi senyawa organik yang terkandung pada bahan baku kompos berlangsung lebih cepat pada perlakuan dibandingkan dengan kontrol. Terjadi mineralisasi $\mathrm{C}$ organik beserta kandungan organik menjadi senyawa anorganik yang akan lebih mudah dimanfaatkan oleh tanaman. Data tersebut di atas didukung oleh adanya perubahan tekstur kompos. Tekstur kompos yang terbentuk nampak berbeda antara kompos yang diberi inokulum dengan yang tidak diberi inokulum. Tekstur kompos perlakuan nampak relatif lebih halus dan berwarna lebih gelap dibandingkan dengan kontrol. Ini menunjukkan dekomposisi senyawa organik berlangsung lebih cepat pada perlakuan dibanding pada kontrol. Penambahan kompos kotoran sapi pada media tanam bibit apel menunjukkan adanya respon positif terhadap pertumbuhan tunas tanaman apel. Terbukti dari adanya kecenderungan bahwa tunas yang tumbuh di media berkompos memiliki ukuran lebih panjang daripada yang tumbuh di media tanpa kompos.

Mikrohabitat tanaman apel akan dipengaruhi oleh penambahan kompos. Manipulasi mikrohabitat ini juga dapat dilakukan dengan menerapkan sistem penyiangan yang berbeda sehingga mempengaruhi keberadaan tanaman penutup tanah (TPT) (gambar 2). Hasil penelitian menunjukkan bahwa Indeks Diversitas (ID) pada lahan pertanian dengan sistem ss $(1,03)$ paling
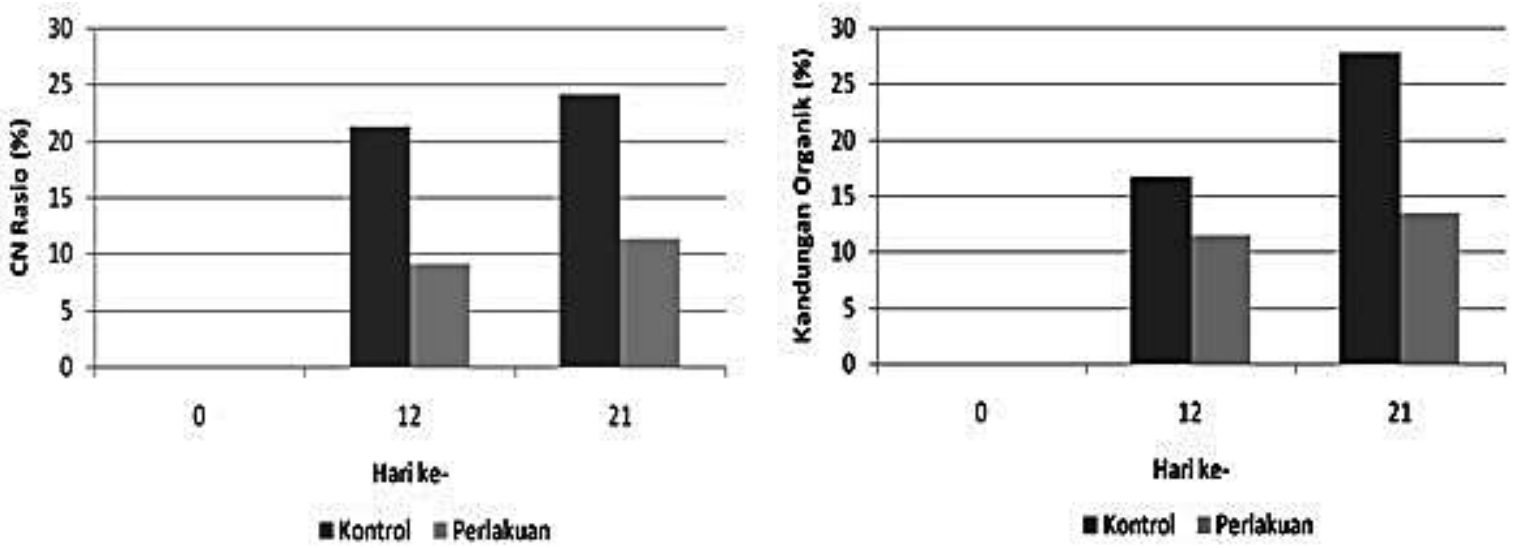

b

Gambar 1. Grafik persentase penurunan CN rasio dan kandungan organik antara perlakuan dan kontrol rendah dan cs $(2,04)$ paling tinggi akibat adanya campur tangan petani apel dalam memanipulasi TPT. Pada lahan ss, diversitas TPT sangat rendah karena lahan apel juga dipergunakan untuk menanam kacang tanah yang memerlukan perawatan intensif terhadap gulma. Sebaliknya, pada lahan cs, diversitas TPT sangat tinggi karena introduksi lebih dari satu jenis tanaman budidaya memberikan mikro habitat yang lebih baik pada berbagai TPT. Introduksi beberapa tanaman budidaya ini juga meningkatkan ID vegetasi pada lahan cs. Berbeda halnya dengan lahan sj yang kurang mendapatkan campur tangan manusia, ID lahan ini $(1,75)$ berada diantara ID lahan ss dan cs.

Data ID tersebut didukung oleh nilai dominansi relatif (Dr) yang menunjukkan adanya dominansi pada lahan ss oleh spesies Blebekan dengan nilai $\operatorname{Dr} 58,74$ (cara perhitungan tidak ditampilkan). Kodominansi terjadi pada lahan pertanian sj oleh spesies Kokrokan $(36,08)$, Banyuan $(24,19)$ dan Blembem $(23,78)$ sedangkan pada lahan pertanian cs juga terjadi kodominansi oleh spesies Kolo $(26,92)$, Patikan $(23,55)$ dan Wedusan (12,56). Adapun INP masing-masing jenis vegetasi pada tiap-tiap lahan adalah berbeda. Pada lahan ss, tiga spesies dengan INP paling tinggi adalah Blebekan, Kacang tanah dan Ulang-ulang sedangkan pada lahan sj adalah Kokrokan, Blembem dan Banyuan adapun pada lahan cs adalah Kolo, Wedusan dan Patikan. Tingginya INP menunjukkan bahwa spesiesspesies tersebut mempunyai peranan yang lebih besar untuk menentukan sifat habitat dan kondisi lingkungan pada masing-masing lahan pertanian apel. 


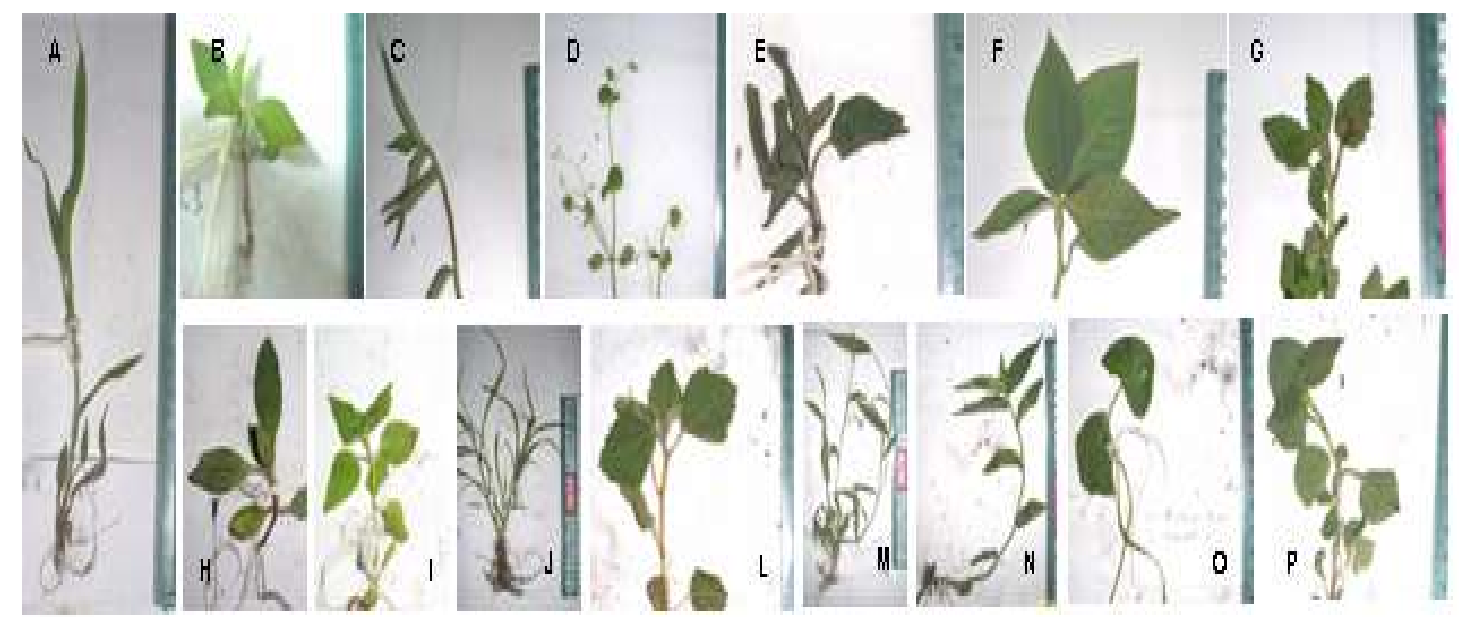

Gambar 2. TPT pada Lahan Apel: A. Grinting, B. Wedusan, C. Kolo, D. Blimbingan, E. Ranti, F. Patikan, G. Gajahan, H. Blebekan, I. Kuningan, J. Ulang-ulang, L. Keresan, M. Kokrokan,N. Blembem, O. Blimbingan Besar, P. Banyuan

Tanaman penutup tanah diduga sangat mempengaruhi habitat tanaman apel. Hal ini ditunjukkan oleh nilai suhu tanah semakin menurun ketika biomassa TPT semakin besar. Kondisi lahan cs dan sj yang tampak lebih stabil berdasarkan nilai ID, Dr, INP, dan nilai biomassa tanaman. Biomassa yang lebih tinggi menyebabkan suhu tanah lebih rendah karena jumlah TPT yang banyak pada lahan sj, meskipun tidak beragam, mengakibatkan air banyak terkandung di jaringan.

\section{KESIMPULAN}

Kandungan beberapa nutrisi makro untuk tanah pertanian apel Bumiaji menunjukkan nilai rata-rata yang berada pada kisaran sedang dan tinggi. Hasil analisis makro nutrisi daun apel yang kemudian dibandingkan dengan standar menurut Utah Fertilizer Guide menunjukkan bahwa makro nutrisi N, P, Ca berada pada status normal, $\mathrm{K}$ berada pada status kurang dan $\mathrm{Mg}$ berlebih. Ketersediaan nutrisi di tanah dapat dipelihara dengan penambahan kompos. Kotoran sapi yang diperkaya dengan bakteri indigen mampu mendekomposisi kotoran sapi dalam waktu 2-3 minggu. Proses dekomposisi kotoran sapi berlangsung lebih cepat pada pemberian bakteri indigenus yang mempunyai kemampuan selulolitik dan sekaligus proteolitik serta amilolitik apabila dibandingkan kontrol yang tanpa pemberian inokulum bakteri. Pada pertanian apel di Poncokusumo, kondisi lahan cs (cukup sering) dan sj (sangat jarang) tampak lebih stabil daripada ss (sering sekali) berdasarkan nilai ID (indek diversitas), Dr (dominansi relatif) dan INP (indek nilai penting). Hal ini diperjelas oleh nilai biomassa tanaman. Biomassa yang lebih tinggi menyebabkan suhu tanah yang lebih rendah karena jumlah TPT yang banyak mempunyai konsekuensi mengandung banyak air pada jaringannya.

\section{DAFTAR PUSTAKA}

1. Surabaya Post. 2009. Harga Naik, Para Petani Apel Kembali Tersenyum.http:// www.surabayapost.co.id. Tanggal akses 9 Oktober 2009

2. Ristek. tanpa tahun. Apel (Malus sylvestris Mill). Kantor Deputi Menegristek Bidang Pendayagunaan dan Pemasyarakatan IImu Pengetahuan dan Teknologi. http://www. ristek.go.id. Tanggal akses 12 Februari 2007

3. Rideout, J. W. 2002. Soil Facts, Soil and Plant Analysis for Apple Trees. North Carolina Cooperative Extension Service. Carolina. US

4. Nachtigall, G. R. and Dechen, A. R. 2006. Seasonality of Nutrients in Leaves and Fruits of Apples Trees. Sci.Agric. (Pirocacababa, Braz.) 63.5:493-501

5. Paul, E. A. 2007. Soil Microbiology, Ecology, and Biochemistry. $3^{\text {rd }}$ ed. Elsevier. Singapore

6. Apun. K, B. C. Jong, and M. A. Salleh. 2000. Screening and Isolation of a Cellulolytic and Amylolytic Bacillus from Sago Pith Waste. J. Gen Appl. Microbiol 46: 263-267.

7. Cotta, M. A. 1988. Amylolytic Activity of Selected Species of Ruminal Bacteria. Applied \& Environmental Microbiology

8. Meager dan Meyer. 1990. Effects of Ground Cover Management on Certain Abiotic and Biotic in Peach Orchard Ecosystems. Crop Protection Journal 9: 65-72 
9. Smith, G. D., W. C. Stiles dan R. W. Weires. 1989. The Effects of Ground Cover Manipulations on Pest and Predator Mite Populations on Apple in Eastern New York. New York's Food and Life Sciences Bulletin Number 128.

10. Hartley, M. J., A. Rahman, K. C. Harrington dan T. K. James. 2000. Assessing Ground Covers in a Newly Planted Apple Orchard. New Zealand Plant Protection Journal 53: 2227

11. James, D. W. And K. F. Topper. 1993. Utah Fertilizer Guide. Utah State University. Utah.

12. Sari, Y. M. 2004. Hubungan Kelas Kesesuaian Lahan dengan Nilai Baku N, P, K untuk Tanaman Apel (Malus sylvestris Mill) di Poncokusumo, Malang. Skripsi. Jurusan Tanah. Fakultas Pertanian. Universitas Brawijaya.

13. Dris, R. 2002. Influence of Potassium Nutrition in Commercial Apple Orchards. Plant Nutrition Growth and Diagnosis. Science Publishers, Inc. Enfield. New York.

14. Dris, R. 2002. Magnesium Nutrition in Apple Orchards. Plant Nutrition Growth and Diagnosis. Science Publishers, Inc. Enfield. New York.

15. Merhaut, J. D. 2007. Chapter 6: Magnesium. Handbook of Plant Nutrition, edited by $A$. V.Barker and D. J. Pibeam. CRC Press Taylor and Francis Group. USA. New York. 